\title{
Morocco as a possible domestication center for barley: biochemical and agromorphological evidence
}

\author{
J.L.Molina-Cano ', P.Fra-Mon ${ }^{2}$, G.Salcedo ${ }^{2}$, C.Aragoncillo ${ }^{2}$, F. Roca de Togores ${ }^{1}$ \\ and F. García-Olinedo ${ }^{2}$ \\ - Department of Barley Brecding. La Cruz del Campo, S.A., Malting and Brewing Company, P.O. Box 53, E.4 loso Strillit. Spain \\ 2 Department ol Biochenisiry, Escuela Tecniea Superior de Ingenieros Agrononos, Universidad Politesnica, E-2\%040 Mialrial, Spain
}

Summary. The distribution of genetic variants of a group of low molecular weight, chlorolorm-methanol soluble proteins (CM proteins), among Morocean and non-Moroccan accessions of Hordeum sponianeum and among selections from several Moroccan landraces of $H$. vilgare and cultivars of the same species with widespread European origin, suggests that domestication of barley might have taken place in Morocco. An agromorphological characterization of the $H$. spontaneum accessions further supports this hypothesis. The possible Moroccun origin of the French cultivar 'Hatif de Grignon' and of several Spanish 6-rowed barleys is also presented.

Key words: Wild barley - Hordeum - Domestication Center of Origin

\section{Introduction}

Cultivated barley (Hordeum vilgare L.) has been considered, on the basis of its evolutionary pattern, as an oligocentric crop; this means that barley has a definable center of origin, the Fertile Crescent, and one or more centers of diversity, for instance Ethiopia (Harlan 1975).

The center of origin of a crop may be defined as the region where domestication took place and can be recognised because there the wild aricestor survives together with its derived crop. The wild species is usually living in a wild status in the core of its range and, sometimes, survives as a weed at the periphery of it (Zohary 1964). The discovery of $H$. spontaneum C. Koch as a weed of barley in Morocco (MolinaCano and Conde 1980; Molina-Cano et al. 1982) enlarged the know western limits of the area of distribution of the witd ancestor of cultivaled barley, which were previously thought 10 be Cyrenaica, in the easl of Libya (Harlan and Zohary 1966;
Harlan 1979). Al about the same time, Chinese workers reported the occurrence of H. spomtank'um in the QinghidiXizang plateatu of China (Xu 1982). Tolay, therefore, both the easitern and western limits of the areat of distribution of wild barley have been considerably enlarged and, consequently, the Fertile Crescent can be called into question as the only center of origin of barley. More recently, Bekele (1983) has argued for the possibility of a multiple origin of cultivated barley.

Giles and von Bothmer (1985) arguted that it is very dilficult to state whether Morocco-and-China are true centers of origin of barley or should rather be considered as secondary centers.

Molina-Cano et al. (1982) put forward the following 2 alternative hypolheses to explain the oxcurrence of H. sponaneam in Morocso: i) It was formerly wild there and has survived after becoming a weed. ii) It wis introduced there in historical times, presumably as an admixiure with barley seteds coming from elsewhere, possibly from line Near East.

For making the correct choice among the two former hypotheses it is necessary to study the genetic relationships umong the Moroccan weed barleys and their counterparts from other regions of its range, particularly from the core of the Fertile Crescent, i.e., Istael, Irac, Syria, Iran, etc., but also from other peripheral regions such as Libya and Afghanistan. As suggested by Harlan (1980, personat communication) Libya is indeed a very critical region in this conkext. Genetical difierences between the Moroccan and the olher wild barley populations would tend to exclude the second hypothesis, that of the introduction of $\boldsymbol{H}$. spontanetun into Morocio from elsewhere, and would support the first hypothesis, that of a domestication carried out in situ. Gites and Leikovited (1984, 1985) found clear diflerences among Moroccan and Iranian accessions of $\boldsymbol{H}$. spontaneum, both in germination pattern and in agromorphology.

In addition, the study of the genetical relationships among Morocican weed barleys, Moroccan cultivaled barleys, and southern Europian cultivaled barleys should also ofler some insights into the origin of the latter.

In our survey, we have investigited the genetic variability of the CM-proteins, which are the main components of the A-hordeins (Salcedo el al. 1980 , 1982). The A-hordeins are less variable both in the cultivated and in the wild species than the B-, C- and 
D-hordeins (Doll and Brown 1979; Shewry et al. 1979, 1983) and are, therefore. more suilable biochemical markers in phylogenetical studies. Wheat CM-proteins were among those used by Johnson and coworkers in their extensive studies on the origin and evolution of Aegilops-Triticum species (Johnson 1972, 1975: Johnson and Hall 1965). Our survey has been complemented with an agromorphological study of the $H$. spontaneum accessions.

\section{Materials and methods}

We present in Table 1 , the name, origin, source of seed and pedigree, where known, of all the cultivars and accessions studied. The 8 accessions of H. spontaneum from Moroceo are all the avisilable material collected in the 2 expeditions reported by Molina-Cano and Conde (1980) and Molina-Cano et al. (1982). Each of the 8 populations of weed barley was collected us a group of about 15-20 single spikes; they were not yet completely mature and therefore unthreshed. These populations have since been conserved in isolation as singlespike progenies. The composile of Morocean landraces of cultivated burley was formed by bulking logether grain from single spikes of the 9 original populations. This bulk was sampled alterwards on the bisis of the agromorphological appearance of its individual component plants. The accessions from Cyrenaica (Libya) were kindly sent us by Dr. K. Hammer (Zentratinstitut für Genetik und Kulturptlanzenforschung, German Democratic Republic). The remaining accessions of $H$. spontaneum from some of the relevant regions of its range of distribution, were kindly supplied by Dr. J. C. Craddock (USDA World Barley Collection).

- The cullivated barleys sampled could be divided into 4 groups: i) Lindraces (fom Morocco; ii) primitive cultivars of Spanish and French origin that were, in turn, derived from landraces; iii) modern French culitivars; iv) European cultivars of non-Meditertanean origin.

\section{Biochemicul meshods}

The extraction and 2-dimensional fractionation of barley CMproteins was carried out essentially as described by Salcedo et al. (1984), on single kemels from the progenies of individual spikes of each population studied.

Delipidated kernels were extracted twice with chloroform: methanol 2: I $(v / v)$ and the solvent vacuum-evaporated. The extracts were fractionated by 2-dimensional gel electroplioresis: the first dimension was a $\mathrm{pH}$-gradient electrophoresis on preformed $\mathrm{pH}$ gradients (ampholines 5-8), and the second onc, a starch-gel electrophoresis ( $\mathrm{pH} 3.2$ ). Gels were stained with $0.05 \%$ nigrosine, in methanol-waler-acetic acid $(5: 5: 1$ by vol). To ascertain the relative positions of different protein variants in the 2-dimensional maps, electrophoresis of mixtures of the appropriate samples was carried out.

\section{Agromorphological siudies}

The characters studied were mainiy chosen to give a picture, as complete as possible, of the differences among the accessions of $H$. sponioneum. From the set of 28 characlers studied, only 8 of them, listed in Table 2, gave significant differences among accessions, when analyses of variance were carried out.

\section{Results}

\section{Variation in $C M$-proteins (A-hordeins)}

The CM-proteins were analyzed by 2-dimensional electrophoresis in all the $H$. spontaneum and $H$. vulgare samples listed in Table 1 . Figure 1 is a composite diagram where the relative positions of all the variants are shown in the 2-dimensional matp. The CM-proteins are low molecular weighi, salt-soluble hydrophobic polypeptides that are selectively extracted from barley endosperm with chloroform: methanol $2: 1(\mathrm{v} / \mathrm{v})(\mathrm{Sal}-$ cedo et al. 1980). The standard phenotype, that of 'Zephyr' barley, consists of 5 components: CMa-1, CMb-1, CMc-1, CMd-1 and CMe-I (Fig. 1, black spots). Variants for these proteins were identilied on the basis of their alternative appearance in the survey and, in the case of the more frequent ones, by studying their inheritance in appropriate crosses (Silcedo et al., 1984). Results are summarized in Table 3.

The variani proteins CMe-2,2' were found in 7 out of $8 \mathrm{H}$. spontaneum accessions trom Morocco; in 12 out of $14 \mathrm{H}$. vulgare (6-rowed) accessions also from Morocco and, finally, in the French cultivar 'Hatif de Grignon' and its derivatives 'Precoce Lepeuple', 'Monlon', 'Astrix', and 'Hop', all of the 6-row type.

These variants seem thus to be restricted to Moroccan weed and cultivated barleys and, also, to some French cultivars. Two line-selections ('Anezal' nos. 2 and 4) from the same Morocean landrace carried CMe-I and $\mathrm{CMe}-2,2^{\prime}$, respectively, indicating that the original population was segregating at the $C M e$ locus. This landrace was not included in the bulk that originated accessions A-L. Several single plants from this landrace

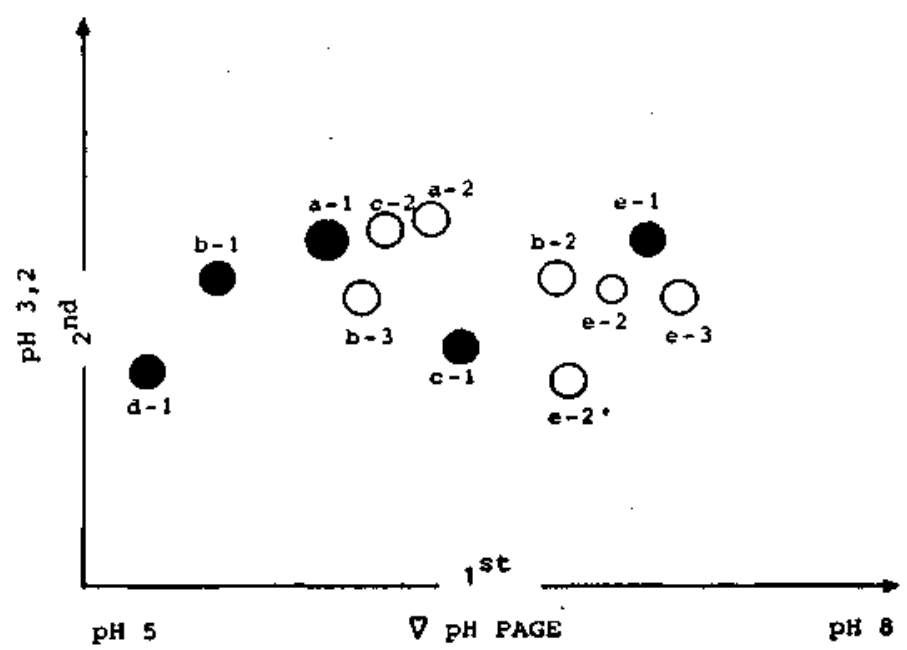

Fig. 1. Composite diagram showing relative positions in the 2-dimensional map and designations of all observed variants (black spots correspond to proteins lound in the "standard phenotype" of Hordeum vulgare, cv. 'Zephyr') 
Table 1. Description of barley material used (cultivafs of accessions)

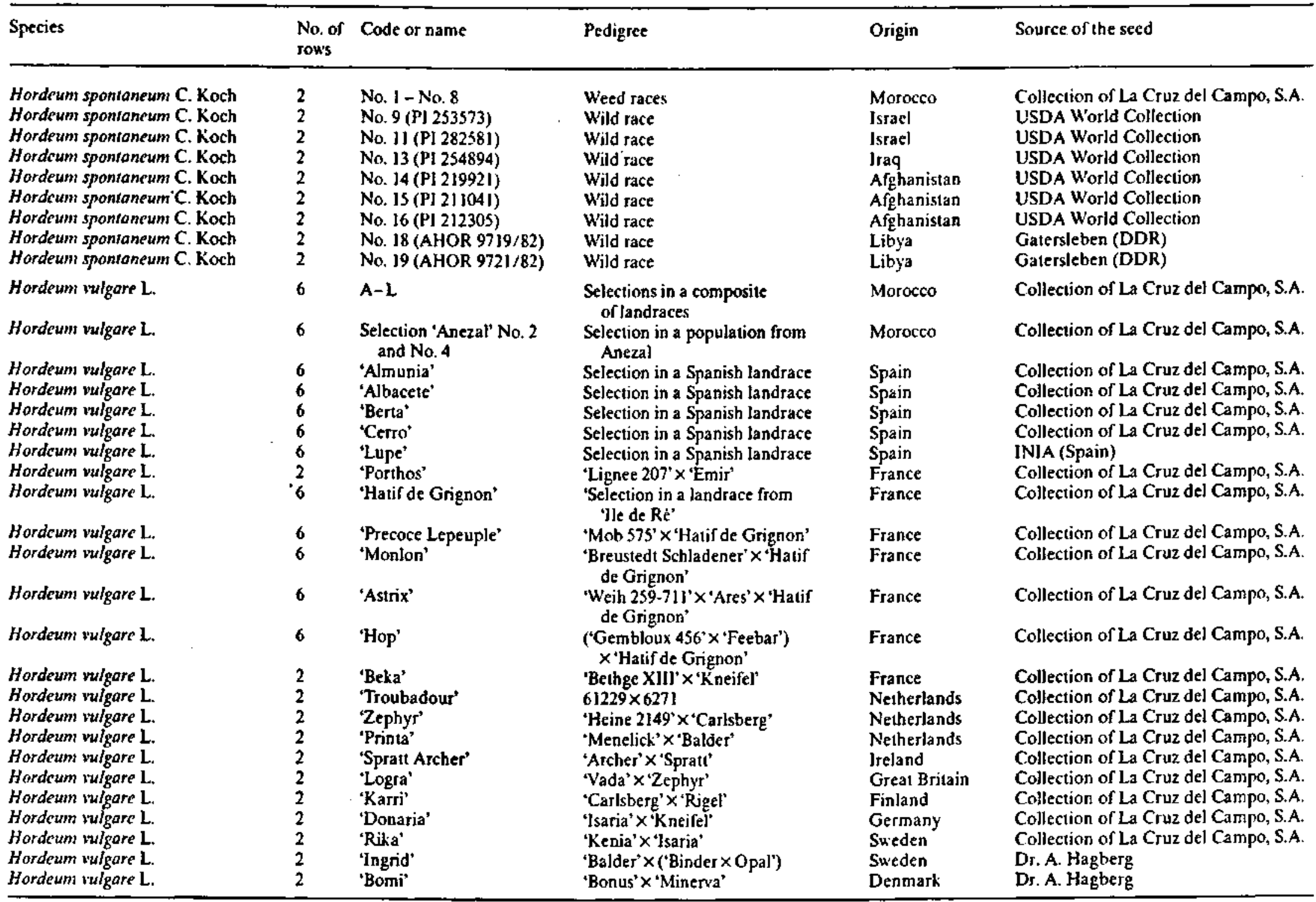


Table 2. Agromorphological characterisation of Hordesm sponsaneum accessions*

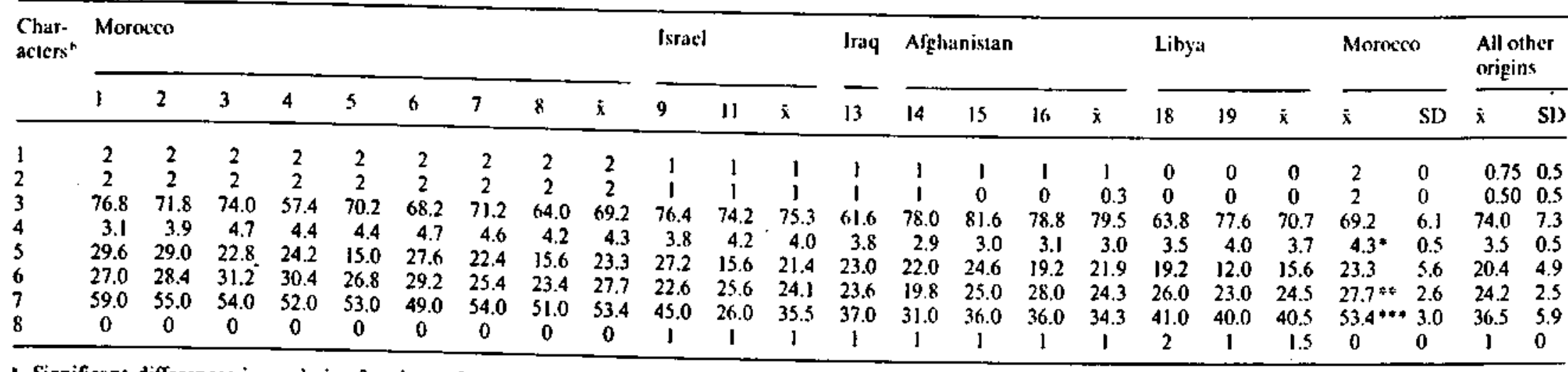

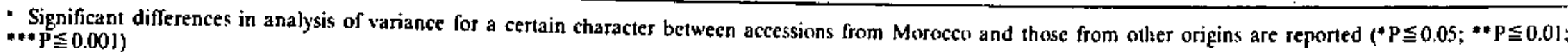

- List of charac

prostrate; 2: erect 3. Ptani hess at heading stage. Codes. 0: Low foliage developnent: 1: medium; 2: strong. 2. Plant habj1 at heading stage. Codes. 0: prosirate: 1: semipact; 1 : intermediate; 2 : lax

Table 3. Phenotypes observed in the electrophoretic analysis of $\mathrm{CM}$ proteins in Hordcum spontaneum and $H$. vulgare

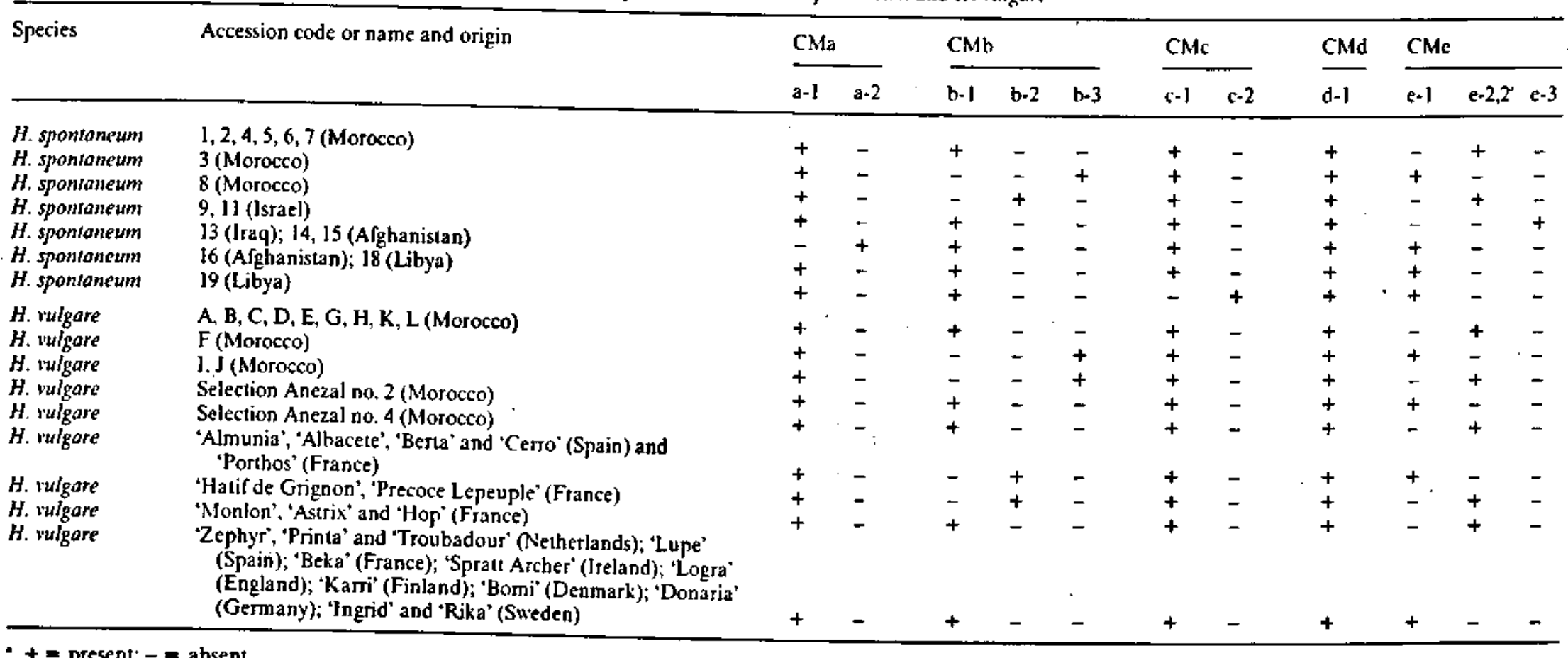

\footnotetext{
$+=$ present; $-=$ absen
} 
were collected by Molina-Cano, Gomez-Campo and Conde during their 1980 trip, near the village of Anczal, in the surroundings of the Djebel Siroua, in a thin stand of barley cultivated in an isolated field. The selections were made on the basis of agromorphological appearance.

The varianl CMb-3 was found only in Moroccan material, both cultivated of the 6-row type and weed.

The allele CMb-2 has been found in Morocean $H$. spontaneum, in 4 out of 5 Spanish 6-rowed cultivars, and in the 6-rowed French cultivars 'Hatif de Grignon' and its derivative 'Precoce Lepeuple', and in the 2rowed 'Porthos'.

Some protein variants were found only in wild barleys outside Morocco: CMa-2 in H. spontaneum from Iraq and Alghanistan, CMc-2 from Libya, and CMe-3 from lsrael.

Protein CMd-I was found to be invariant among all the studied material.

\section{Variation in agromorphological characters}

The relevant results are presented in Table 2 . The accessions of H. sponsaneum from Morocco have a high loliar development and an ereet habit at heading, as well as tillers that are significantly shorter and thicker than those of the accessions from other origins. More. over, their yielding ability is much higher for they have a signiticantly higher thousand-kernel weight and number of grains per spike and, also, a higher tillering capacity - number of spikes per plant. Besides, the Moroccan weed barley has a spike denser than that of $H$. spontaneum from the other origins. All these observations indicate that the former is much closer to the culivated species than the other wild barleys studied.

If we examine in Table 2, the similarities of $\boldsymbol{H}$. spontantwm, Morocco, versus $H$. spontaneum Isratl, Iraq, Afghanistan, and Libya, we can conclude that they are very slight. And this is true even when we compare accessions from Morocco and Libya, that are neighbouring countries.

\section{Discussion}

Both the biochemical and the agromorphological data seem to indicate that Morocean weed barleys are clearly different from those from elsewhere, although we should allow for the limited number of nonMoroccan accessions studied. These results are in good agreement with those by Giles and Lefkovitch (1984, 1985). Even the Libyan aceessions are very dissimilar from the Moroccan ones. This implies a long period of isolation of the latter.

The striking phenotypic similarity between $H . \mathrm{vul}$. gare and $H$. spontaneum from Morocco, as well as the distribution of the less frequent protein variant, CMb-3, could be explained in terms of introgression. However, the prevalence of CMe-2,2' in both types of Moroccian barleys is not easily explained by introgression - this allele probably originated there - and suggests that a domesticution provess might have oceured in Moroceo, a situation which would be similitr to those postulated for China (Xu 1982) and Elhiopia (Bektle 1983), regions well apart from the Fertile Crescent.

We could thus conceive the domestication of barley as a process carried out over a continuum of very different environments, j.e., as a noncentric crop, "stensu" Harlan (1975).

The situation in Morocco could be explained as follows: (i) The real wild types would disippear at an undetermined moment after domestication had taken place. This situation might be explained because of the progressive desertization of the Suhara from the 3rd millennium BC onwards (Harlan 1975). Under those drier conditions, the only suitable land for wild barley was restricted to the more humid and favorable environment of cultivated barley fields, where soil moisture was conserved by ploughing. Away from those fields, on the very dry and hard Artemisia steppe, only xerophyles could live. (ii) H. spontaneum was adapted to survive as a weed in cultivated barley fields, then introgression started that led it to its present tevel of similarity with its cultivated companion. A similar situstion is described for Libya by Hammer el al. (1985).

In conclusion, the evidence presented here supports the hypothesis that Morocco is a center of origin of barley, providing we allow for the limited evidence bused on: i) the restricted number of populations analysed, and ii) the small number of protein systems used.

The French cultivar 'Hatif de Grignon' and all its derivatives share with most of the Morocean weed and cullivaled barleys proleins CMe-2,2; which suggests the possible African origin of this variety, which is, in turn, a selection within an old French landrace from lle de Re. This possible Moroccan origin of 'Hatif de Grignon' is in agreement with its known good adiptation to arid regions, particularly in Spain. Four out of five Spanish varieties share with 'Hatif de Grignon', 'Irecoce Lepeuple' and 'Porlhos', all of French origin, the allele $\mathrm{CMb}-2$, which is also carried by the Moroccan H. spontanewm no. 8. This evidence favours the sug. gestion of the presumed Moroccan origin of "Hatif de Grignon' and further supports the North African origin of the Spanish 6-rowed barleys (Wiebe 1968).

Acknowledgements. We acknowledge the technical assistance of J. Garcia-Guijarro. The work at Madrad has been supported by grant No. 2022/83 from Comision Asesora de Investigacion Cientifica y Tecnica. 


\section{References}

Bekele E (1983) A differential rate of regional distribution of barley flavonoid patterns in Ethiopia, and a view on the center of origin of barley. Hereditas 98:269-280

Doll H, Brown AD (1979) Hordein variation of wild (Hordeum spontonemm $\mathrm{C}$. Koch) and cultivated (H. valgare L.) barley. Can J Genet Cytol 21:391-404

Giles BE, Lefkovisch LP (1984) Diflerential germination in Hordeum spontaneum from lran and Morocco. Z Pllanzen7ücht 92:234-238

Giles BE, Leikovitch LP (1985) Agronomic differences in Hordeum sponianeum from Iran and Morocco. Z Pflanzenzücht 94:25-40

Giles BE, Bothmer $R$ von (1985) The progenitor of barley (Hordeum vulgare spp. sponioneum) - its importance as a gene resource. Sver Utsaedestoeren Tidskr 95:53-61

Hammer K, Lehmann Chr O. Perrino P (1985) Character variability and evolutionary trends in a barley hybrid swarm - a case sludy. Biol Zentralbl 104:511-517

Harlan JR (1975) Crops and man. Am Soc Agron Crop Sci Soc Am, Madison Wis, Pp 6-9

Harlan JR (1979) Barley. In: Simmonds NW (ed) Evolution of crop plants. Longman, London, pp 93-98

Harlan JR, Zohary D (1966) Distribution of wild wheats and barley. Science 153:1074-1080

Johnson BL (1972) Protein electrophoretic profiles and the origin of the B genome of wheat. Proc Natl Acad Sci USA 69: $1398-1402$

Johnson BL (1975) Identification of the apparen $\mathbf{B}$ genome donor of wheat. Can J Genet Cytol 17:21-39

Johnson BL, Hall O (1965) Analysis of phylogenetic afinitics in the Triticinae by protein electrophoresis. Am J Bot 52: $506-513$
Molina-Cano JL, Conde J (1980) Hordenm spontaneum C. Koch emend Bacht. collected in southern Morocco. Barley Genet Newslett 10:44-47

Molina-Cano JL, Gomez-Campo C, Conde J (1982) Hordeum sponsaneum $\mathrm{C}$. Koch as a weed of barley lields in Morocco. Z. Pflanzenzüchı 88: 161-167

Salcedo $G$, Fra-Mon P, Molina-Cano JL, Aragoncillo $C$, Garcia-Olmedo F (1984) Gentics of CM-proteins (Ahordeins) in barley. Theor Appl Genet 68:53-59

Salcedo G, Sanchez-Monge R, Aragoncillo C (1982) The isolation and characterization of low molecular weight hydrophobic salt soluble proteins from barley. J Exp Bot $33: 1325-1331$

Salcedo G, Sanchez-Monge R, Argamenteria A, Aragoncillo C (1980) The A-hordeins as a group of sall soluble hydrophobic proteins. Plint Sci Letl 19:109-119

Shewry PR, Finch RA, Parmar S, Franklin J, Miflin BJ (1983) Chromosomal Jocation of Hor-3, a new locus governing storage proteins in barley. Heredily 50; $179-190$

Shewry PR, Pratl HM, Faulks AJ, Parmar S, Miflin BJ (1979) The sturage protein (hordein) polypeptide pattern of barley (Hordeum vulgare L.) in relation to varielial identification and disease resistance. J Natl Inst Agric Bot 15:34-50

Wiebe GA (1968) Intraduction of barley into the New World. In: Barley origin, bolany, culture, winteshardiness, genetics, ultilizátion, pests. USDA Agric Handbook No 338, Washington DC, $\mathrm{p}^{3}$

$\mathrm{Xu}$ TW (1982) Origin and evolution of cultivated barley in China. Acta Genei Sinica 9:440-446 (Irom Plant Breed Abstr 53:593-594, 1983)

Zohary D (1964) Spontineous brittle six-row barleys, their nature and origin. In: Broekhuizen S, Dantuma G, Lamberls $H$, Lange W (ed) Barley genetics, voll. Podoc; Wageningen, pp 27-31 